\title{
Orexin/hypocretin levels in the cerebrospinal fluid and characteristics of patients with myotonic dystrophy type I with excessive daytime sleepiness [Corrigendum]
}

Omori Y, Kanbayashi T, Imanishi A, et al. Neuropsychiatr Dis Treat. 2018;14:451-457.

On page 451, the Result section in the abstract, 2nd sentence reads "There were significant differences in the ESS scores and MSL between decreased and normal CSF orexin groups in DM1 patients" it should have been "Differences of the ESS scores and MSL between decreased and normal CSF orexin groups were insignificant among DM1 patients". and is the official journal of The International Neuropsychiatric Association (INA). The manuscript management system is completely online and includes a very quick and fair peer-review system, which is all easy to use. Visit http://www.dovepress.com/testimonials.php to read real quotes from published authors. 